\title{
PROMOTING COOPERATION \\ IN SUPPLY CHAIN \\ AS AN ADVANCED \\ MANAGEMENT TOOL
}

\author{
Agnieszka Goździewska-Nowicka
}

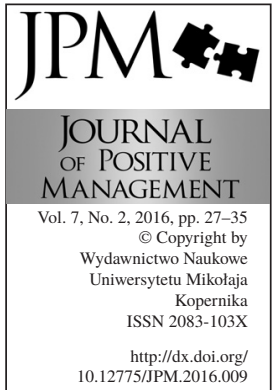

UTP University of Science and Technology in Bydgoszcz,

Faculty of Management, Bydgoszcz, Poland

e-mail: agnieszka.gozdziewska@utp.edu.pl

\begin{abstract}
Purpose: The purpose of this paper is to present benefits for various supply chain links, which are managed by leader who successfully promoting cooperation. Also presented a theoretical culture of trust and teamwork model, based on four key pillars. Furthermore, it describes the most important indications for supply chain leadership in promoting co-operation.

Design/methodology/approach: This paper presents only a theoretical approach. All information has been characterized on the basis of literature.

Findings: An article describes a number of benefits, which organizations can achieve if they cooperate. Key benefits of using based on co-operation model are considered: increase competitiveness of the company through participation in the structures to ensure survival (the possibility of selling goods and services), establish business contacts with other companies, reduction of time and costs paid by client, reduction of the uncertainty action, keeping delivery times, increase reliability of supply, reducing pollution and harmful effects of processes on the environment. Presented benefits clearly indicate that organizations which are in a supply chain can achieve much more than companies which act alone.

Research and practical limitations/implications: Conclusions, which are summary of the article can provide guidance to supply chain leaders.

Originality/value: The paper can provide value for people involved in supply chain management, both leaders and supply chain members. Originality of this article is difficult to assess because article presents a theoretical, not empirical issues.
\end{abstract}

Keywords: promoting, cooperation, supply chain management

Paper type: Literature review

\section{Introduction}

The coordinator role of activities in a supply chain plays chain leader. A decision regards fore front of the whole chain is dependent on company position, its 
PROMOTING COOPERATION IN SUPPLY CHAIN

Agnieszka

Goździewska-Nowicka economic power, size and authority. Supply chain leader should take care of all the targets to set for chain, but also to effectively promote cooperation between its cells. This means that the main task of leader is skillfully involving people and groups that often are not formally subordinate to him, to the inspiring work on common goals, despite differences in beliefs, cultural values and norms of action.

It should be emphasized that presented in this article approach to supply chain management is the exact opposite of command-and-control model. Propagated approach can be described as promoting cooperation leadership.

Supply chain management is a difficult area of organization activity. The more links are in a chain, the bigger risk of organizational problems can occur. Today, companies that want to maintain a competitive advantage must learn to interact with other organizations. The success factors for companies operating in the market is to focus on their core competencies and ensuring proper development of relations with suppliers and customers. Only such an approach can now ensure success and high efficiency of the supply chain (Varsei, 2016).

An important element of cooperation between supply chain links is making changes in their relationship. Between companies forming common operation network there is no agreement based on the concept of transactional, but now it is a relationship built on the concept of cooperation. A key issue arising from this concept is mutual trust and implement the strategy of "win - win" that leads to the creation of a logistics partnership (Kifor et al., 2012). This kind of partnership existed between entities creating an integrated supply chain gives the chance to effectively confront the competition and creates the conditions to meet the needs of buyers.

The aim of the article is to present the benefits for various supply chain links, which are managed by the leader who successfully promoting cooperation. Also presented a theoretical culture of trust and teamwork model, based on four key pillars. Furthermore, it describes the most important indications for supply chain leadership in promoting co-operation.

\section{Supply chain links - the process of creating a cooperation model}

Enterprises, which build together supply chain, are doing this because they see in this action some tangible benefits. Collectively implementation of tasks means to achieve the synergies and execute such projects, that alone would not be feasible.

High awareness of leader who manages the supply chain allows to distribute between remaining links the idea of community-oriented cooperation. The key issue is to constantly encouraging people to constantly use their talents required for functioning of the whole chain. Because in the organizations striving to achieve a common goal is supported by the organizational structure of these companies, it is possible to use the talents and expertise of knowledge workers to the needs of flexible projects, the results of which will serve all links in. Such activities 
encourage both innovation, agility, but also greater performance and scalability (Adler et al., 2012).

It is worth noting that more and more companies concedes that they achieve more benefits through collaborative thinking. An example would be IBM, whose management emphasizes that with proper approach to the cooperation issue with their suppliers and colleagues, they were able to obtain significantly higher margins from the implementation of activities that require intensive knowledge. In addition, they were able to reduce errors by $75 \%$ over six years and to increase its efficiency by about $10 \%$ per year, in addition to create more innovative and technologically advanced products. All this brilliant achievements were possible to implement thanks to the introduction of certain organizational changes, closely related to cooperation. The pillars of these changes are four points (Koźmiński and Piotrowski, 2000):

1) defining a common goal, then its implementation,

2) observance of ethical contribution,

3 ) creating processes that allow people to carry out joint projects,

4) build a system in which cooperation is appreciated and rewarded.

The concept of social relations by Max Weber is based on four pillars. They are: self- interest, emotional bond, tradition and a common goal. May think what Weber and his concept have in common with cooperation in the supply chain? But it turns out that it can be found some significant relationships. Companies focused on a single operations network have decided to take this step, because it has moved them to the irresistible desire to get their own benefit. Many times companies use tradition as a means for motivating teams. On the other hand, many subordinates often feel a strong emotional bond with respect to their leader and this allows them to efficiently perform task. The fourth pillar is the most important, as it is a common goal makes supply chain for organizations seeking to build such a platform for trust and organizational cohesion, which will be more important than the self-benefit, more flexible than tradition and more durable than emotional ties.

For each supply chain link the common goal is something that shows how a group can position themselves in relation to its competitors and partners, and what activities to customers and the wider community will be success determinants. It is worth noting that this common goal does not constitute a permanent essence of business activity, only describes what each of the employees involved in work for the various links in chain is trying to achieve.

The common goal connects all links in supply chain and becomes a kind of beacon for action in all cooperating entities at all organizational levels. Starting from development activities strategy through planning and organizing, and ending on the work execution.

Unfortunately, leaders have some difficulties with establishing a common goal for whole integrated supply chain. Then they resorted to the overall design. They 
PROMOTING COOPERATION IN SUPPLY CHAIN

Agnieszka

Goździewska-Nowicka need to be aware of the fact that development of a common purpose is not an easy task, but on the contrary it is often a long and complicated process. However, not only a matter related to the well-identified objective of common chain enables operators to function efficiently, but above all relevant communicate those objectives. It turns out that in organizations where employees clearly understand direction of the company and are adequately informed about strategic goals, this culture of cooperation is very high, and as a consequence of this collaboration is more effective (Warzybok, 2012).

The term "contribution ethics" also refers to cooperation as valuable to the organization are all those employees who go beyond their own training schemes to bring the whole community to achieve a common goal. It should be highlighted that being oriented cooperation is not synonymous with the proper performance of their work and responsibilities. In many companies, the situation can be observed which indicating that the hard work of individual workers does not bring good collective result. Therefore, following the contribution ethics, should make the employees wished to go beyond their formal responsibilities, so as to solve broader and more complex problems, and not just focus on their modest participation in the execution of a single task. In addition, the recommendation of the contribution ethics is also a strong individualism to replace the model of group work.

Another pillar to which supply chain links must heed when they want to build a business model based on co-operation is the establishment of interdependent processes. It is necessary to underline that common goal turns out to be a worthless idea when held by workers skills and responsibilities will not be able to contribute to its achievement. In many organizations, including those that form the supply chain, there are problems with the development of horizontal relations of the company and the conduct of interdependent activities. In the supply chain is particularly serious obstacle, because all his links should be mutually aligned and perfectly interact with each other. To this kind of coordination could function effectively is necessary to use such techniques as such: process mapping, kaizen and just big attention to recording the results of meetings, brainstorming sessions. The use of this form of process management in an organization is quite difficult. It requires from employees to change their previous habits. Employees usually receive information on the operations and procedures for its implementation, and able to operate within those limits according to their ideas. In the proposed cooperation oriented model, employees must learn that the services they will need to be constantly monitored, in terms of adapting them to the needs of others.

The last of the pillars on which rests a model of cooperation is a working system. When the work is done in teams and when more employees come to the teams, and that undoubtedly happens in the supply chain, it becomes necessary to create a new kind of power structure. It should be designed to used the knowledge 
of each employee and to the flow of this knowledge was correct, and therefore useful for everyone.

Summing up the above discussion on a cooperation oriented model can be add that the use of such an approach is also a great motivator for employees. This is what makes people so willing to carry out their tasks in networking is mainly that they treat other challenges as a new round of higher level in the same game (Kidder, 1981). Looking more broadly at the issue can be concluded that people just talk about who contributed the biggest amount to the joint work.

Cooperating companies in supply chain are concerned not only about their business, but also for interests of all the other chain partners. When interests of any company differ from interests of the other, its actions will not increase efficiency of the whole chain. Companies must therefore cooperate in such a way that pursuit of one company to maximize revenues caused maximizing performance of the whole supply chain. Creating incentives for greater efficiency is possible through free exchange of information with suppliers and customers, it is mainly about the current knowledge of changes in supply and demand, enabling quick response. It is also important to define roles, tasks and responsibilities of suppliers and customers, and equitable risk sharing, costs and profits resulting from introduction of new initiatives (Lee, 2005).

There can occur also some difficulties, that arise when organization focused on cooperation are build. Establishing and coordinating processes that bring people from different teams together, requires constant attention. What's more, stimulate and sustain a sense of common purpose can meet with difficulties resulting from changes in the market. In turn, employees of companies that are in the based on cooperation supply chain must be constantly involved in activities of larger teams.

Not all projects made by cooperating supply chains are successful. In the search for competitive advantages resulting from partnership should take into account aspects that are cited as reasons for failure of such relationships. These are (Hoyt and Hug, 2000):

1) lack of continuous and mutual trust,

2) changes in the market,

3) see partner as a potential competitor,

4) excessive duration of a project.

There cannot be also expected that partners from the beginning of cooperation will demonstrate features of full openness. Transformation of initial relationships to partnerships can give rise to conflicts or disappointment associated with different stages of the expected result of partial closer cooperation. It requires both sides empathy, which eventually turns into a trust. That it was one of the key factors characterizing partnerships, allowing free flow of information, protects supply chain by risks associated with fluctuations in demand. 
PROMOTING COOPERATION IN SUPPLY CHAIN

Agnieszka

Goździewska-Nowicka

\section{Leader in the supply chain and promotion of cooperation}

Today's reality makes business people more frequently than they used to take extensive action at the professional level. Their task is to cooperate not only within their own organization, but also need to collaborate with customers, suppliers, institutions or universities. Links cooperating in the supply chain are well aware of this type of action. But this is only one organization becomes the leader of the chain. Being a leader in the supply chain depends on how strong is a company, what kind of economic situation has, how big it is and who is the president. It turns out that not all top-level managers are aware of how important it is to promote cooperation and they do not have the relevant expertise in this area.

Leader promotes cooperation in the supply chain must have the skills in four areas (Ibarra and Hansen, 2012):

1) playing the role of connector,

2) attracting diverse talent,

3) setting an example of cooperation at the top of the corporate hierarchy,

4) managing teams in a determined way.

The term "connector" may be associated with a person who has many connections with different social environments. However, the number of such links isn't the most important, but the ability to connect people, ideas and resources, which in other circumstances would be impossible to link to. In business connectors are very important cooperation coordinators.

The connector is recognized in the business world as a very important way to create value for the company. Thanks to connectors is possible to build links between employees of the supply chain and the outside world. It should be emphasized that promoting cooperation leaders should make contacts not only in the obvious way, or through industry associations or meeting places clients with suppliers, but also in very unusual circumstances and locations. There can be also build a network of contacts with representatives of adjacent industries, innovation centers, because everything opens the door to new business opportunities and take partnership.

Another element supporting a leader is to engage talent. Research consistently shows that interdisciplinary teams get better results, of course, they must be properly managed. The role of any leader is to unite people of different backgrounds, from different organizational cultures and skillfully use everything they have to offer. It is unacceptable to permit outstanding and talented employees who are in each of the links in the supply chain, have been subjected to a process of unification. Thanks to high diversity of personnel, which is observed in supply chains, can prove their strong competitive advantage. Cooperation in such a diverse team, composed of many members, each coming from a different organization (same chain) can also cause frequent conflicts at the professional 
level, linked to a different opinion on a specific topic. It is also an advantage that can be achieved through cooperation, as well managed, constructive conflict can lead to discovering the best ideas (Muntean, 2014).

Leaders who want to promote co-operation must remember about refreshing their team. They should regularly take care of new players, who appear in supply chain. Simple but obvious way to recovery of any organization is to introduce generation Y employees in its structure. These individuals are considered technically gifted, because practically since their birth they have contact with the latest technologies and are able to efficiently and effectively use the benefits of technology, including in the field of business .

The next area of which the supply chain leader need to remember is cooperation at the top. Currently, engaging the most talented people and perception of the need for cooperation are no longer enough to succeed. Leaders are forced to show the direction of the appropriate action by their own behavior. In the supply chain it is so much difficult for some managers, because they still perceive other links as competitors, not those with whom they work closely together and have a common goal.

When the leader effectively encourage the supply chain links to work, he must still deal with a certain, often appearing problem. It is simply an exaggeration. People sometimes cross the borders of cooperation and it seems to them that all initiatives can be done jointly. In such situations, the most common are convened endless meetings, during which the same ideas are discussed and, consequently, so is unable to reach a consensus. Moreover, such activities do not help to take a quick decision and then such cooperation poses a kind of threat to the organization. That's why the leader must be efficient and manage teams efficiently and consistently, so as to maintain organizational agility and form and dissolve advisory teams, depending on possible needs. Leaders also need to remember that they allocate to their subordinates decision-making powers, so that in due time they finished the discussion and made a decision.

Following these instructions is able to provide head leaders a long-term supply chain success. However, they must also focus on a few key principles. Namely, they need every day to try to exploit the people potential, resources and ideas. But to do this, it is necessary to transform talent management strategy and building strong relationships not only within the cooperating organization, but most of all its need to create relationships with the outside world. Leaders must know when it's time to finish the unproductive debate and not to waste any more time, and how to influence colleagues.

The tasks of a leader standing at the top of supply chain are multi-faceted. Emerging differences in views, values and cultural norms often impede cooperation activities, because the cause that is too complex. On the other hand, this diversity makes that cooperation may prove to be more innovative and more 

COOPERATION IN SUPPLY CHAIN

Agnieszka

Goździewska-Nowicka
PROMOTING

valuable. And it is these values should be the goal for a leader who promote cooperation.

\section{Conclusions}

The element of cooperation between the supply chain links is extremely important. Unfortunately observing organizations within the supply chains on the Polish market, there is seen lack of complementary knowledge in this field. Businesses interact with each other, but they do it only for their personal financial gain. They often have no awareness that the formation of close cooperation, such as the one described on the basis of a model based on cooperation, would give definitely greater benefits both financial and also social, substantive and associated with strategic initiatives.

For the key benefits of using a model based on co-operation should be considered:

- increase competitiveness of the company through participation in the structures to ensure the survival (the possibility of selling goods and services),

- establish business contacts with other companies,

- reduction of time and costs paid by client,

- reduction of the uncertainty action,

- keeping delivery times,

- increase reliability of supply,

- reducing pollution and harmful effects of processes on the environment.

Presented above benefits clearly indicate that organizations that are in the supply chain can achieve much more than the company acting alone. Not all entrepreneurs are convinced to the idea of cooperation, so it's important to emphasize the benefits that can be achieved and the widespread promotion of the initiative in scientific work.

\section{References}

Adler, P., Heckscher, Ch., Prusak, L. (2012), "Jak zbudować firmę nastawioną na współpracę", Harvard Business Review Polska, No. 108/02, avalilable at: https://www. hbrp.pl/a/jak-zbudowac-firme-nastawiona-na-wspolprace/17EoPAnxT (accessed 9 December 2016).

Hoyt, J., Hug, F. (2000), "From arms - lenght to collaborative relationships in the supply chain. An evolutionary process", International Journal of Physical Distribution \& Logistics Management, Vol. 39 No. 9, pp. 758-759.

Ibarra, H., Hansen, M. T. (2012), “Czy jesteś liderem promującym współpracę?”, Harvard Business Review Polska, No. 108/02, avalilable at: https://www.hbrp.pl/a/czy-jestesliderem-promujacym-wspolprace/BKGW0JOj (accessed 9 December 2016).

Kidder, T. (1981), The Soul of a New Machine, Boston: Little, Brown. 
chain management focusing on procurement processes and suppliers", International Journal of Engineering, Vol. 10 No. 2, pp. 77-82.

Koźmiński, A., Piotrowski, W. (2000), Zarzqdzanie. Teoria i praktyka, Wydawnictwo Naukowe PWN, Warszawa.

Lee, H. L. (2005), "Sekret najbardziej efektywnych łańcuchów dostaw”, Harvard Business

PROMOTING COOPERATION IN SUPPLY CHAIN

Agnieszka

Goździewska-Nowicka Review Polska, No. 25, pp. 78-92.

Muntean, S. N. (2014), "Talent management and its contributions to the performance of the multinational organizations", Revista Academie Fortelor Terestre, Vol. 19 No. 3, pp. 300-306.

Varsei, M. (2016), "Sustainable Supply chain management: a brie literature review", Journal of Developing Aeas, Vol. 50 Special Issue, pp. 411-419.

Warzybok, M. (2012), "Warunki sprawnej współpracy", Harvard Business Review Polska, No. 108/02, avalilable at: https://www.hbrp.pl/a/warunki-sprawnej-wspolpracy/ MdRweqb7 (accessed 9 December 2016).

Wexler, S. (2010), "IBM Unveils New Products, Services and Strategy", Channel Insider, No. $2 / 23$. 